\title{
Diabetic Control in 102 Insulin-treated Out-patients
}

\author{
G. Tchobroutsky ${ }^{1}$, D. Charitanski ${ }^{1}$, Y. Blouquit ${ }^{2}$, L. Papoz ${ }^{3}$, J. Soria ${ }^{1}$, and J. Rosa ${ }^{2}$ \\ ${ }^{1}$ Hôpital de l'Hôtel-Dieu, Université Pierre et Marie Curie, Paris, ${ }^{2}$ Hôpital Henri Mondor, Creteil, \\ and ${ }^{3}$ Unité de Recherches Statistiques de l'INSERM, Villejuif, France
}

Summary. Haemoglobin $A_{1 c}$ concentrations were measured in 102 insulin-treated diabetic outpatients. Only $19 \%$ had $\mathrm{Hb} \mathrm{A}_{1 \mathrm{c}}$ levels below three standard deviations above the normal mean value $(5.23 \pm 0.05 \%)$. There were no correlations between $\mathrm{Hb} \mathrm{A}_{1 \mathrm{c}}$ levels, random C-peptide immunoreactivity or age. A significant correlation $(\mathrm{r}=0.49 ; \mathrm{p}<$ 0.001 ) was, however, observed between $\mathrm{HbA}_{1 \mathrm{c}}$ and random plasma glucose levels. The mean random plasma glucose value was normal $(89 \pm 18 \mathrm{mg} /$ $100 \mathrm{ml} ; 5 \pm 1 \mathrm{mmol} / \mathrm{l})$ in the patients on insulin three times a day who had received short acting insulin 160 $\pm 6 \mathrm{~min}$ before the sampling. - A significant inverse correlation was found $(\mathrm{r}=-0.26 ; \mathrm{p}<0.01)$ between the number of daily insulin injections and the $\mathrm{HbA}_{1 \mathrm{c}}$ concentration. - These results suggest that the use of multiple daily insulin injections improves diabetic control. It should however be emphasised that the patients receiving multiple insulin injections were younger than those on the single injection regime and had lower plasma insulin antibody titres, different social and psychological status and a shorter duration of the disease.

Key words: Haemoglobin $A_{1 c}$ - Insulin-dependent diabetes - Blood glucose control - Multiple insulin injections.

Until recently definite criteria have been lacking for the quantification of the degree of control of diabetes [1]. Measurement of haemoglobin $\mathrm{A}_{1 \mathrm{c}}\left(\mathrm{HbA}_{1 \mathrm{c}}\right)$ concentrations has proved to be useful in the assessment of diabetic control since there is an inverse correlation with the quality of control of diabetes during the 2 months preceding $\mathrm{Hb} \mathrm{A} \mathrm{Ac}_{1 \mathrm{c}}$ determinations [2-6].
Gonen et al. [7] screened 230 diabetic patients to analyse the overall quality of control in a diabetic clinic that aims to achieve tight control. Only $13 \%$ of insulin-treated patients had $\mathrm{HbA}_{1}$ concentrations within three standard deviations (SD) of the mean value in a group of non diabetics.

The aim of this study was to assess the quality of control in unselected insulin-dependent out-patients treated by insulin according to various clinical factors, particularly age, socio-economical handicaps and the number of daily insulin injections. Several groups have shown that insulin twice or three times a day facilitates control [8] even in unstable patients [9]. We have shown in short term studies that divided daily doses of insulin lowered post-prandial blood glucose levels [8], reduced 24 hour urinary sugar excretion [10] and resulted in higher plasma insulin levels $[11,12]$ than conventional insulin regimes. Such a regime probably inhibited the development of retinal microaneurysms during a 4 year observation period $[13,14]$.

\section{Patients and Methods}

Insulin-treated diabetic patients who came for their regular outpatient visit with their own physician were in addition seen by one of us during a two week period and blood was drawn for estimation of $\mathrm{HbA}_{1 \mathrm{c}}$, plasma glucose, C-peptide immunoreactivity and measurements of insulin antibody concentration.

All patients were studied in the post prandial state, that is either in the morning between $0900 \mathrm{~h}$ and $1300 \mathrm{~h}$ (between the breakfast and the midday meal) or in the afternoon between $1400 \mathrm{~h}$ and $1700 \mathrm{~h}$ (between the lunch and the afternoon snack).

The mean post-meal sampling time was $163 \pm 8 \mathrm{~min}$ with no significant statistical differences between the different insulin regime groups.

Patients gave informed consent for blood sampling. Those coming for their initial visit were not included in the study. The others were regular out-patients attending all but one of the physicians in the clinic. Two samples were not suitable for the study 
because of the presence of abnormal haemoglobin ( $\mathrm{S}$ and $\mathrm{C}$ ). One hundred and two patients were studied. We classified the patients according to their socio-economic status as defined by the French INSEE professional classification [15]. Severe social or psychological handicaps were defined by one or more of the following features: a) very low income i. e. three lowest INSEE income classes (out of 10); b) unemployement for more than 3 months in the last year; c) immigrants with no or poor knowledge of French language; d) one or more visits to a psychiatrist during the last year. All the patients were or have been treated by beef insulin or by a mixture of beef and pork insulin.

$\mathrm{HbA}_{1 \mathrm{c}}$ concentrations were measured according to an original technique to be published elsewhere [16]. In brief, this method consists of medium-pressure chromatography on a column of BIOREX 70, 200-400 mesh, using an automatic peptide analyser as previously described [17] with minor modifications [16]. This method uses three different phosphate buffers, and results in a clear cut separation of the peak of $\mathrm{HbA}_{1 \mathrm{a}+\mathrm{b}}$ from the peak of $\mathrm{HbA}_{1 \mathrm{c}}$ and that of $\mathrm{HbA}$. Samples are introduced successively by a automatic sampler, optical densities determined at $568 \mathrm{~nm}$, and the areas under the peaks calculated by a in-line computing integrater. Twenty four samples can be analysed in $24 \mathrm{~h} . \mathrm{Hb} \mathrm{F}, \mathrm{HbS}$ and $\mathrm{HbC}$ are easily detected because their presence modifies the shape of the curves.

Normal values were taken from the results obtained in 49 proven non-diabetic adults aged between 22 to 51 years. (mean = $5.23 \pm 0.05 \%$ ). Intra and inter assay coefficients of variation were $<3.2 \%$ and $<8 \%$ respectively.

Plasma glucose was assayed with the Beckman glucose analyser.

C-peptide immunoreactivity was measured using the Daiichi radioimmunoassay kit [18] Guerbet Test - France - Radioisotope Laboratories, Tokyo. According to the supplier, cross-reaction with human proinsulin is $7 \%$ on a molar basis. All the assays were run together. Standard curves include several controls including known samples with low and high values. The lowest sensitivity for C-peptide in our hands was $0.15 \mathrm{ng} / \mathrm{ml}$.

Insulin antibodies were detected according to Rosselin et al. [19] by incubating sera at final dilutions of $1: 10,1: 20$ and $1: 50$ in $1 \mathrm{ml}$ of buffer containing $100 \mu \mathrm{l}$ of human plasma and $0.03 \mathrm{ng}$ of human iodinated insulin (human insulin Novo ${ }^{\mathbb{B}}$; specific activity $240 \mu \mathrm{Ci}$ / $\mu \mathrm{g}$, CEA Saclay $\mathrm{n}^{\circ} 73045$ A) for 5 days at $+4^{\circ} \mathrm{C}$. Free and bound insulin were then separated using talcum powder [20]. The concentration of plasma antibodies was estimated by counting the percentage of bound iodinated insulin as compared to the amount adsorbed by the talcum powder in the presence of $100 \mu$ l of normal human plasma. A high plasma insulin and antibody titre was defined by $20 \%$ or more of the tracer being bound by plasma diluted to $1: 50$.

Comparisons were done using analysis of variance, the Pearson correlation coefficient, Student's t test and the chi-square test. The observed distributions of $\mathrm{HbA}_{1 \mathrm{c}}$ concentrations appeared to be normal. All results are presented as mean \pm SEM.

\section{Results}

Clinical data for the 102 diabetic patients treated with insulin are given in Table 1 for each insulin regime. The mean age was $47 \pm 2$ years with a duration of diabetes of $13.2 \pm 1.0$ years. Severe socioeconomic or psychological handicaps were docu- mented in 14 subjects below 60 years most of whom were in the group of patients receiving one daily insulin injection.

Analysis of variance showed that the higher the number of daily insulin injections, the younger the patients, the shorter the duration both of the disease and of the insulin therapy and the higher the daily insulin dosage. There were no differences in the frequency of out-patient visits (about 3 per year).

$\mathrm{HbA}_{1 \mathrm{c}}$ concentrations and other biological variables are shown in Table 2.

Of the patients $19 \%$ had $\mathrm{HbA}_{1 \mathrm{c}}$ values below 3 SD above the mean of the non diabetic group. The higher the number of insulin injections the better the results $(r=-0.26 ; p<0.01)$. Only one of the 25 patients on one injection daily, had $\mathrm{HbA}_{1 \mathrm{c}}$ values below $3 \mathrm{SD}$ as compared to 21 and $33 \%$ for the subjects on 2 or 3 injections per day respectively.

It should be emphasised however that the patients receiving multiple insulin injections differed in several ways from those on the single insulin regime (Tables 1 and 2). They were younger, had lower plasma insulin antibody titres, different social and psychological status and a shorter duration of the disease.

To improve the objectivity of the comparisons between groups we also studied $\mathrm{HbA}_{1 \mathrm{c}}$ concentrations after eliminating the patients in the groups on once and twice daily injections who were older than the oldest patient in the thrice daily injection group and withdrawing the 14 patients with severe social or psychological handicaps.

The results showed lower $\mathrm{HbA}_{1 \mathrm{c}}$ values in the twice daily injection group than in those on single injection, and lower plasma glucose levels in the thrice daily injection group than in either of the two other groups; the average age was also lower in the thrice daily injection group (Table 3 ). The diabetics on multiple daily injections $(2+3)$ had significantly lower $\mathrm{HbA}_{1 \mathrm{c}}$ concentrations than those on single injection $(p<0.05)$. Plasma glucose levels and age were not significantly lower.

The overall mean random plasma glucose level was $186 \mathrm{mg} / \pm 10 \mathrm{mg} / 100 \mathrm{ml}(10.8 \pm 0.5 \mathrm{mmol} / \mathrm{l})$. Individual mean values were high, around $200 \mathrm{mg} /$ $100 \mathrm{ml}(11.1 \mathrm{mmol} / \mathrm{l})$ in patients receiving insulin once or twice a day. Patients on long acting insulin who were seen in the morning had lower glucose levels than those who came in the afternoon (140 \pm 29 versus $274 \pm 28 \mathrm{mg} / 100 \mathrm{ml} ; \mathrm{p}<0.005$ ). This was not true for people on two daily injections (morning value of $185 \pm 23$ versus $204 \pm 14 \mathrm{mg} / 100 \mathrm{ml}$ in the afternoon). Plasma glucose levels were very low in patients who received short acting insulin in the morning and before lunch and did not differ between 
Table 1. Clinical data

\begin{tabular}{|c|c|c|c|c|c|}
\hline & \multirow[t]{2}{*}{ All diabetics } & \multicolumn{4}{|c|}{ Number of insulin injections per day } \\
\hline & & 1 & 2 & 3 & $\mathrm{p}^{\mathrm{a}}$ \\
\hline Number of patients & 102 & 25 & 62 & 15 & \\
\hline Males & $60 \%$ & $50 \%$ & $61 \%$ & $66 \%$ & NS \\
\hline Age (years) & $47 \pm 2$ & $56 \pm 4$ & $46 \pm 2$ & $34 \pm 3$ & $<0.001$ \\
\hline Duration of diabetes (years) & $13 \pm 1$ & $17 \pm 2$ & $13 \pm 1$ & $7 \pm 1$ & $<0.05$ \\
\hline Duration of insulin therapy (years) & $10 \pm 1$ & $13 \pm 2$ & $10 \pm 1$ & $6 \pm 1$ & $<0.01$ \\
\hline Insulin dosage $\mathrm{U} /$ day & $43 \pm 2$ & $33 \pm 2$ & $45 \pm 2$ & $54 \pm 5$ & $<0.05$ \\
\hline Handicaps in subjects below 60 & & 6 out of 11 & 7 out of 50 & 1 out of 15 & \\
\hline Mean frequency of out-patient visits in last year & $3.1 \pm 0.2$ & $3.1 \pm 0.2$ & $3.2 \pm 0.2$ & $2.7 \pm 0.3$ & NS \\
\hline
\end{tabular}

a Overall comparison between the 3 groups by analysis of variance (quantitative data) or by Chi-Square test (qualitative data)

Table 2. Laboratory data of diabetic patients

\begin{tabular}{|c|c|c|c|c|c|}
\hline & \multirow[t]{2}{*}{ All diabetics } & \multicolumn{4}{|c|}{ Number of insulin injections per day } \\
\hline & & 1 & 2 & 3 & $\mathrm{p}$ \\
\hline Number & 102 & 25 & 62 & 15 & \\
\hline $\mathrm{HbA}_{1 \mathrm{c}} \%$ (range) & $\begin{array}{c}7.4 \pm 0.1^{\mathrm{a}} \\
(4.4-11.5)\end{array}$ & $\begin{array}{c}8.1 \pm 0.2 \\
(5.3-9.9)\end{array}$ & $\begin{array}{c}7.3 \pm 0.2 \\
(4.5-11.5)\end{array}$ & $\begin{array}{c}6.9 \pm 0.4 \\
(4.4-10.6)\end{array}$ & $<0.05^{\mathrm{b}}$ \\
\hline$\%$ below mean normal value $+3 \mathrm{SD}$ & $19 \%$ & $4 \%$ & $21 \%$ & $33 \%$ & $<0.05$ \\
\hline Plasma glucose $\mathrm{mg} / 100 \mathrm{ml}(\mathrm{mmol} / \mathrm{l})$ & $\begin{array}{l}186 \pm 10 \\
(11 \pm 1)\end{array}$ & $\begin{array}{l}211 \pm 23 \\
(12 \pm 1)\end{array}$ & $\begin{array}{l}199 \pm 12 \\
(11 \pm 1)\end{array}$ & $\begin{array}{l}89 \pm 18 \\
(5 \pm 1)\end{array}$ & $<0.001^{c}$ \\
\hline IR C-peptide $\mathrm{mmol} / \mathrm{ml}$ (range) & $\begin{array}{c}0.47 \pm 0.04 \\
(0.13-2.55)\end{array}$ & $\begin{array}{l}0.54 \pm 0.10 \\
(0.16-2.35)\end{array}$ & $\begin{array}{c}0.50 \pm 0.05 \\
(0.13-2.55)\end{array}$ & $\begin{array}{c}0.28 \pm 0.03 \\
(0.14-0.57)\end{array}$ & NS \\
\hline $\begin{array}{l}\% \text { of subjects with high insulin antibody titres } \\
\text { (see text for definition) }\end{array}$ & $24 \%$ & $36 \%$ & $30 \%$ & $0 \%$ & $<0.05^{\mathrm{c}}$ \\
\hline
\end{tabular}

${ }^{a} \mathrm{p}<0.001$ for comparison with the 49 non diabetic subjects $(5.23 \pm 0.05$; range $4.51-5.82)$

b Overall comparison between the 3 groups by analysis of variance

c Three injections versus two or versus one injection. Two versus one: NS

Table 3. Results in patients on one, two or three daily insulin injections after correction for age and social or psychological handicaps. (See text for definitions)

\begin{tabular}{|c|c|c|c|c|c|c|}
\hline & & \multicolumn{5}{|c|}{ Number of insulin injections per day } \\
\hline & & 1 & 2 & 3 & $2+3$ & Significance \\
\hline \multicolumn{2}{|c|}{ Number of patients } & 10 & 40 & 11 & 51 & \\
\hline \multicolumn{2}{|l|}{$\mathrm{HbA}_{1 \mathrm{c}} \%$} & $8.0 \pm 0.4$ & $7.0 \pm 0.2$ & $7.3 \pm 0.5$ & $7.1 \pm 0.2$ & a \\
\hline \multicolumn{2}{|c|}{$\begin{array}{l}\text { Plasma glucose } \mathrm{mg} / 100 \mathrm{ml} \\
(\mathrm{mmol} / \mathrm{l})\end{array}$} & $\begin{array}{c}193 \pm 41 \\
(10.7 \pm 2.2)\end{array}$ & $\begin{array}{c}196 \pm 16 \\
(10.8 \pm 0.8)\end{array}$ & $\begin{array}{c}87 \pm 23 \\
(4.8 \pm 1.2)\end{array}$ & $\begin{array}{l}172 \pm 15 \\
(9.5 \pm 0.8)\end{array}$ & b \\
\hline \multicolumn{2}{|c|}{ Age (years) } & $45 \pm 3$ & $42 \pm 2$ & $33 \pm 4$ & $40 \pm 2$ & c \\
\hline \multicolumn{7}{|c|}{$\begin{array}{ll}{ }^{\mathrm{a}} \mathrm{HbA}_{1 \mathrm{c}}: & 2 \text { versus } 1=\mathrm{p}<0.05 \quad 1 \text { versus } 3=\mathrm{NS} \\
& 2+3 \text { versus } 1=\mathrm{p}<0.05 \quad 2 \text { versus } 3=\mathrm{NS}\end{array}$} \\
\hline b glucose: & $\begin{array}{l}3 \text { versus } 1=1 \\
3 \text { versus } 2=1\end{array}$ & $\begin{array}{l}.01 \text { versus } 2 \\
.01 \quad 1 \text { versus } 2\end{array}$ & $=\mathrm{NS}$ & & & \\
\hline c age: & $\begin{array}{l}3 \text { versus } 1= \\
3 \text { versus } 2=\end{array}$ & $\begin{array}{l}1 \text { versus 2 } \\
15 \\
1 \text { versus 2 }\end{array}$ & $=\mathrm{NS}$ & & & \\
\hline
\end{tabular}




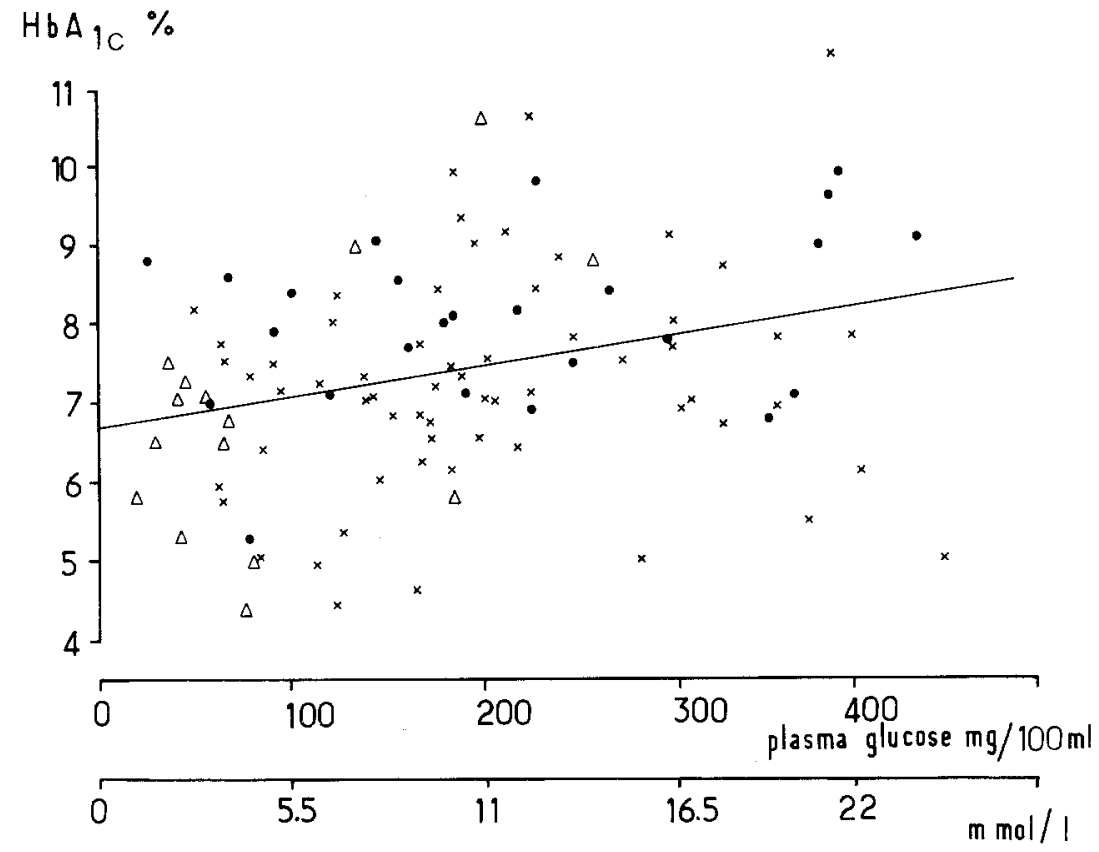

Fig. 1. Correlation of non fasting plasma glucose concentration and the percentage of $\mathrm{HbA}_{1 \mathrm{c}}$ in 102 insulin-treated diabetic patients. $\mathrm{y}=0.004 \mathrm{x}+6.7$ ( $\mathrm{x}$ in $\mathrm{mg} /$ $100 \mathrm{ml}) ; \mathrm{r}=0.49 ; \mathrm{p}<0.001 . \bullet=$ one injection per day $-X=$ two injections per day $-\triangle=$ three injections per day morning and afternoon. Sampling was carried out about $2^{1 / 2}$ hours after the breakfast or the midday meal with no differences between groups $(166 \pm 8$; $166 \pm 4$ and $160 \pm 6 \mathrm{~min})$.

Random C-peptide immunoreactivity for all the patients after a meal gave a mean value of $0.47 \pm$ $0.04 \mathrm{pmol} / \mathrm{ml}$. Very low concentrations were observed in the patients on short acting insulin with low plasma glucose levels. Differences in C-peptide values between patient groups were not significant.

Insulin antibodies were more often present in high concentration in patients on insulin once or twice a day than in those on three injections per day $(\mathrm{p}<0.05)$.

No correlation was found between $\mathrm{HbA}_{1 \mathrm{c}}$ concentrations and C-peptide levels nor between plasma glucose and C-peptide levels. Random plasma glucose concentrations were significantly related to $\mathrm{HbA}_{1 \mathrm{c}}$ levels in the population studied $(\mathrm{r}=0.49$; $\mathrm{p}<0.001$ ) and particularly in the three daily injection group (Fig. 1). We did not find any relationship between age and $\mathrm{HbA}_{1 \mathrm{c}}$ concentrations.

\section{Discussion}

If good control of blood glucose is worthwhile in the long term as suggested by some recent data in animals and man [21], one should try to achieve exact control in patients with the longest life expectancy. The use of divided daily insulin injections has been advocated by several authors as a better tool than once-daily insulin regimes for this purpose [8-10]. In short term studies we have shown that such a technique resulted in lower post-prandial blood glucose levels [8], lower $24 \mathrm{~h}$ urinary sugar excretion [10] and higher plasma insulin levels $[11,12]$ than with insulin given only once a day. The long term effect of such divided doses of daily insulin could not be analysed since we lacked definite criteria for the quantification of the degree of diabetic control [1]. With $\mathrm{HbA}_{1 \mathrm{c}}$ measurements [2-7] it is possible to analyse the quality of control over cumulative periods of two months in out-patients. Gonen, Rochman and Rubenstein [7] have recently screened 230 diabetic patients including 175 subjects taking insulin. Only $13 \%$ had $\mathrm{HbA}_{1}$ concentrations below $3 \mathrm{SD}$ above the mean. These authors did not find any correlation between insulin antibody concentrations and $\mathrm{HbA}_{1}$ levels [22]. They thought that better results were observed in patients on insulin twice a day than in those with one daily injection (A.R., personal communication).

In the study reported here, the mean quality of diabetic control was very poor since only $19 \%$ of $\mathrm{HbA}_{1 \mathrm{c}}$ values were below $3 \mathrm{SD}$ above our mean normal values. Even with a multiple insulin injection regime 66 to $79 \%$ of $\mathrm{HbA}_{1 \mathrm{c}}$ values were above $3 \mathrm{SD}$.

Patients on divided daily insulin injections were better controlled than those receiving only one. Control was also better in patients on insulin twice a day than in those on one injection and best in those on a 3 injection regime. The results do not allow any definite conclusion on the effects of divided insulin regimes per se on diabetic control (as judged by 
$\mathrm{HbA}_{1 \mathrm{c}}$ measurements) since the three groups differed significantly in age, duration of diabetes, duration and daily doses of insulin therapy, social, cultural, economic and psychological handicaps and also by having less plasma insulin antibodies. Such differences are probably due to the fact that all the physicians who treat diabetic patients in this clinic try to give them a twice daily insulin regime provided that life expectancy justifies such an attitude and there are no other handicaps. The youngest and most motivated subjects are probably most willing to follow such a regime. Conversely, the older and more handicapped subjects are kept on one long acting insulin injection with lesser goals for control. Beischer and associates [23] showed the highest C-peptide reserve and the best control in people on one daily injection. However, those with bad control were changed to twice a day insulin injections.

In our study it is unlikely that patients on a divided insulin regime received special attention from the staff. We so often use a twice or thrice daily insulin regime that this is unlikely to have attracted attention.

As far as plasma glucose results are concerned it should be emphasised that out patients in our clinic did not usually have blood samples taken during their regular visit. During this study they did, but were not aware of it beforehand. The three groups did not differ in the number of annual visits.

The mean plasma glucose value was normal, with many very low individual levels in most of the group of diabetics on 3 daily injections seen during the morning or the early afternoon, that is after they had injected short-acting insulin. This tight control was very probably secondary to the short acting insulin administration which is in agreement with our previous results, which have shown that regular (soluble) insulin induced higher peripheral plasma (exogenous) insulin levels than other insulins $[11,12]$.

In these patients on insulin thrice a day, $\mathrm{HbA}_{1 \mathrm{c}}$ levels were abnormal despite normal plasma glucose levels post-breakfast and lunch. These results may indicate that prolonged control after meals and particularly during the night is not good enough.

Random plasma C-peptide levels were measured systematically. We thought when drawing up the protocol that all groups would show abnormal high plasma glucose levels in the fed state. Since the patients on a thrice daily insulin regime had low plasma blood glucose values, endogenous insulin reserves cannot be excluded.

The patients on the 3 insulin injection regime had high titres of insulin antibody less frequently than other groups but since they were usually of low bind- ing capacity [22] their contribution to control was probably minimal.

In patients on two intermediate insulin injections, plasma glucose levels were not lower in the morning than in the afternoon. Better control could have been obtained at least in the morning by adding or increasing the amount of short acting insulin added to biphasic or isophane insulin.

Finally patients on multiple daily insulin injections had significantly lower $\mathrm{HbA}_{1 \mathrm{c}}$ concentrations than those on a single injection regime where even after correction for age and handicaps the $\mathrm{HbA}_{1 \mathrm{c}}$ levels were grossly abnormal.

It is obviously difficult if not impossible to study the isolated effect of "number of insulin injection per day" independently of other variables, notably the motivation of the patients and the charisma of the physicians.

A pessimistic conclusion would be that since even young and highly motivated diabetics receiving insulin three times a day have abnormal mean $\mathrm{HbA}_{1 \mathrm{c}}$ values, we will have to wait for the artificial pancreas. An optimistic one is, since the lowest mean $\mathrm{HbA}_{1 \mathrm{c}}$ and plasma glucose values was observed in the 3 injection group, that perhaps this might be due, at least in part, to the use of short acting insulin taken before meals.

We would suggest therefore that in subjects with meal habits that do not include carbohydrates at noon it is probably reasonable to use intermediate acting insulin plus short acting insulin twice a day. In other subjects regular insulin before the three daily meals plus intermediate insulin for the night is probably justified in subjects with long life expectancy, reasonable social conditions and a normal psychological state.

Acknowledgements. This study was supported by: Université Pierre et Marie Curie, The Fondation pour la Recherche Médicale Française and the Institut National de la Santé et de la Recherche Médicale (INSERM).

We thank C. Senan, Hôpital Henri Mondor, and N. Desplanque, Hôpital de l'Hôtel-Dieu, for their technical assistance.

\section{References}

1. Lefebvre P, Millet J, Luyckx A (1974) Control of diabetes; an attempt to formulate policy guidelines in a department of medicine. Diabetologia 10: 201-204

2. Koenig RJ, Peterson CM, Kilo C, Cerami A, Williamson JR (1976) Hemoglobin $A_{1 c}$ as an indicator of the degree of glucose intolerance in diabetes. Diabetes 25: 230-232

3. Gabbay KH, Hasty K, Breslow JL, Ellison RC, Bunn HF, Gallop PM (1977) Glycosylated hemoglobins and long term blood glucose control in diabetes mellitus. J Clin Endocrinol Metab 44: 859-864 
4. Gonen B, Rubenstein AH, Rochman H, Tanega S, Horwitz DL (1977) Hemoglobin $A_{1}$ : an indicator of the metabolic control of diabetic patients. Lancet II: 734-737

5. Lanoe R, Soria J, Thibult N, Soria C, Eschwege E, Tchobroutsky $\mathrm{G}$ (1977) Glycosylated haemoglobin concentrations and clinitest results in insulin-dependent diabetes. Lancet II: 1156-1157

6. Gonen B, Rubenstein AH (1978) Haemoglobin $A_{1}$ and diabetes mellitus. Diabetologia 15: $1-8$

7. Gonen B, Rochman H, Rubenstein AH (1979) Metabolic control in diabetic patients: assessment by hemoglobin $\mathrm{A}_{1}$ values. Metabolism 28 (Suppl 1): 448-452

8. Kopf A, Tchobroutsky G, Eschwege E (1973) Serial postprandial blood glucose levels in 309 subjects with and without diabetes. Diabetes 22: 834-846

9. Service FJ, Molnar GD, Rosevear JW, Ackerman E, Gatewood LC, Taylor WF (1970) Mean amplitude fo glycemic excursions, a measure of diabetic instability. Diabetes 19: 644-655

10. Tchobroutsky G (1974) How to achieve better diabetic control? Studies with insulin three times a day. In: Malaisse W, Pirart J (eds) Diabetes. Excerpta Med. Found., Amsterdam, p $667-679$

11. Tchobroutsky G, Kopf A, Eschwege E, Assan R (1973) Serial postprandial plasma insulin levels in 117 subjects with and without diabetes. Diabetes 22: 825-833

12. Tchobroutsky G, Lenormand ME, Michel G, Assan R (1974) Lack of post prandial exercise-induced growth hormone secretion in normoglycemic insulin-treated diabetic men. Horm Metab Res 6: 184-187

13. Job D, Eschwege E, Guyot-Argenton C, Aubry JP, Tchobroutsky $\mathrm{G}$ (1976) Effect of multiple daily insulin injections on the course of diabetic retinopathy. Diabetes 25: 463-469

14. Eschwege E, Job D, Guyot-Argenton C, Aubry JP, Tchobroutsky G (1979) Delayed progression of diabetic retinopathy by divided insulin administration: a further follow-up. Diabetologia 16: 13-15

15. INSEE (1977) Code des catégories socio-professionnelles, 6ème éd. Paris

16. Blouquit $Y$, Rosa J, Senan C (in press) An automatic method for a fast determination of glycosylated hemoglobins using low pressure liquid chromatography: results in 1500 diabetic samples. Clin Chem

17. Blouquit Y, Cohen-Solal M, Braconnier F, Rosa J (1975) Description d'un montage automatique permettant la réalisation de chromatographie de peptides. Biochemie 57: 113-116

18. Kuzuya T, Matsuda A, Saito T, Yoshida S (1976) Human Cpeptide immunoreactivity (CPR) in blood and urine-evaluation of a radioimmunoassay method and its clinical applications. Diabetologia 12: 511-518

19. Rosselin G, Tchobroutsky G, Assan R, Lellouch J, Dolais J, Derot M (1965) Etude quantitative d'anticorps humains antiinsulines animales par la méthode radio-immunologique de Berson et Yalow. Comportement des anti-serums vis à vis d'insulines bovine, porcine et humaine. Diabetologia 1: 33-38

20. Rosselin G, Assan R, Yalow RS, Berson SA (1966) Separation of antibody-bound and unbound peptide hormones labeled with iodine $1-131$ by talcum powder and precipitated silica. Nature 212: 355-357

21. Tchobroutsky G (1978) Relation of diabetic control to development of micro-vascular complications. Diabetologia 15: $143-152$

22. Gonen B, Goldman J, Baldwin D, Goldberg RB, Ryan WG, Blix PM, Schanzlin D, Fritz KJ, Rubinstein AH (1979) Metabolic control in diabetic patients: effect of insulin-secretory reserve (measured by plasma C-peptide levels) and circulating insulin antibodies. Diabetes 28: 749-753

23. Beischer W, Kerner W, Raptis S, Keller L, Beischer B, Pfeiffer EF (1978) Insulin therapy in relation to circulating C-peptide levels. Diabetes 27 (Suppl 1): 235-240

24. Yalow RS, Berson SA (1961) Immunologic aspects of insulin. Am J Med 31: 882-891

Received: May 15, 1979, and in revised form: December 7, 1979

Dr. G. Tchobroutsky

Hôpital de l'Hôtel-Dieu

1 place de Parvis Notre Dame

F-75181 Paris Cedex 04

France 